\title{
Effect of eicosapentaenoic acid ethyl ester on hypothyroid function
}

\author{
M Makino, N Oda, N Miura ${ }^{1}$, S Imamura, K Yamamoto, T Kato, \\ K Fujiwara, Y Sawai, K Iwase ${ }^{2}$, A Nagasaka and $M$ Itoh \\ Department of Internal Medicine, Fujita Health University School of Medicine, Toyoake, Aichi 470-1192, Japan \\ ${ }^{1}$ Research Laboratory of Clinical Medicine, Fujita Health University School of Medicine, Toyoake, Aichi 470-1192, Japan \\ ${ }^{2}$ Department of Surgery, Fujita Health University School of Medicine, Toyoake, Aichi 470-1192, Japan \\ (Requests for offprints should be addressed to M Itoh; Email: mituyasu@fujita-hu.ac.jp)
}

\begin{abstract}
Thyroid hormones affect reactions in almost all pathways of lipid metabolism. It has been reported that plasma free fatty acid (FFA) concentration in hypothyroidism is generally within the normal range. In this study, however, we show that plasma FFA concentration in some hypothyroid patients is higher than the normal range. Symptoms of thyroid dysfunction in these individuals were less severe than those of patients with lower plasma FFA concentrations. From these findings we hypothesized that the change in FFA concentration must correlate with thyroid function. Using an animal model, we then examined the
\end{abstract}

effect of highly purified eicosapentaenoic acid ethyl ester (EPA-E), a n-3 polyunsaturated fatty acid derived from fish oil, on thyroid function in 1-methyl-2-imidazolethiol (MMI)-induced hypothyroid rats. Oral administration of EPA-E inhibited reduction of thyroid hormone levels and the change of thyroid follicles in MMI-induced hypothyroid rats. These findings suggest that FFA may affect thyroid functions and EPA-E may prevent MMI-induced hypothyroidism.

Journal of Endocrinology (2001) 171, 259-265

\section{Introduction}

Thyroid hormones affect reactions in almost all pathways of lipid metabolism (Hoch 1988). Plasma free fatty acid (FFA) is released from triglyceride-rich lipoprotein by lipoprotein lipase and hepatic triglyceride lipase. Although it has been reported that plasma lipoprotein lipase and hepatic triglyceride lipase activities are increased in hypothyroidism (Valdemarsson 1983), several studies have shown that plasma FFA concentration in hypothyroidism is within the normal range (Hamberger et al. 1963, Tulloch et al. 1973, Saunders et al. 1980). Therefore, the relationship between plasma FFA concentration and the hypothyroid state remains unclear.

Fatty acids are important as an energy source and as essential components of the plasma membrane. Plasma membrane is composed of several different categories of lipids and functional proteins. Since fatty acid composition is a major factor influencing the biological functions of plasma membranes, structural and quantitative changes of fatty acids may alter the physical properties of the membrane. Fatty acids, especially polyunsaturated fatty acid (PUFA), may affect cellular functions such as membranebound enzymes (Neelands \& Clandinin 1983), transport systems (Ekokoski et al. 1994) and receptors (Gould et al. 1982). In addition, several studies have shown that PUFAs are ligands for peroxisome proliferator activated receptor $\alpha$
(PPAR a) (Forman et al. 1997, Kliewer et al. 1997). Moreover, PPAR $\alpha$ is related to cell proliferation and differentiation in various cells (Hanley et al. 1998, Kaplanski et al. 2000, Peters et al. 2000).

Eicosapentaenoic acid (EPA), an n-3 PUFA, found in various human tissues, has beneficial effects against several diseases (Kromann \& Green 1980). To determine whether an increase in plasma FFA concentration might affect thyroid function, in the second part of this study we investigated whether eicosapentaenoic acid ethyl ester (EPA-E) might prevent the hypothyroid state in 1-methyl-2-imidazolethiol (MMI)-induced hypothyroid rats.

\section{Subjects and Methods}

\section{Patients and treatment}

The clinical study consisted of 15 unrelated Japanese subjects diagnosed with primary hypothyroidism on the basis of their symptoms and laboratory tests at Fujita Health University Hospital. After diagnosis and having obtained their consent to our study, patients were treated by oral administration of thyroxine at an initial dose of $25 \mu \mathrm{g}$ daily, and subsequently at $25 \mu \mathrm{g}$ every 2 weeks until plasma thyroid-stimulating hormone (TSH) concentration reached normal levels. 
Table 1 Clinical and biochemical characteristics of 15 unrelated Japanese subjects with hypothyroidism. The high and low FFA groups were classified according to their fasting serum FFA levels Each value is the mean \pm S.D.

\begin{tabular}{|c|c|c|}
\hline & Low FFA level & High FFA level \\
\hline \multicolumn{3}{|l|}{ Symptoms (\%) } \\
\hline Fatigue & 100 & 100 \\
\hline Cold intolerance & 63 & 29 \\
\hline Edema & 75 & 43 \\
\hline Dry skin & 75 & 29 \\
\hline Slow speech & 75 & 29 \\
\hline Constipation & 75 & 29 \\
\hline Delay of ATR & 88 & $29^{*}$ \\
\hline \multicolumn{3}{|l|}{ Laboratory data } \\
\hline GOT $(\mathrm{mU} / \mathrm{ml})$ & $61 \cdot 0 \pm 60 \cdot 5$ & $30 \cdot 9 \pm 37 \cdot 3$ \\
\hline GPT $(\mathrm{mU} / \mathrm{ml})$ & $63.9 \pm 91 \cdot 9$ & $19 \cdot 5 \pm 16 \cdot 6$ \\
\hline $\mathrm{CK}(\mathrm{mU} / \mathrm{ml})$ & $331 \cdot 5 \pm 202 \cdot 6$ & $149 \cdot 5 \pm 260 \cdot 4$ \\
\hline Total cholesterol $(\mathrm{mg} / \mathrm{dl})$ & $275 \cdot 0 \pm 95 \cdot 5$ & $261 \cdot 7 \pm 51 \cdot 8$ \\
\hline Triglyceride $(\mathrm{mg} / \mathrm{dl})$ & $176 \cdot 8 \pm 39 \cdot 7$ & $126 \cdot 7 \pm 71 \cdot 4$ \\
\hline HDL cholesterol (mg/dl) & $28 \cdot 8 \pm 9 \cdot 3$ & $59 \cdot 3 \pm 28 \cdot 8$ \\
\hline$\beta$-lipoprotein (mg/dl) & $150 \cdot 3 \pm 188 \cdot 9$ & $498 \cdot 3 \pm 150 \cdot 3$ \\
\hline FFA $(\mathrm{mEq} / \mathrm{l})$ & $0 \cdot 17 \pm 0 \cdot 05$ & $0 \cdot 88 \pm 0 \cdot 24^{*}$ \\
\hline \multicolumn{3}{|l|}{ Thyroid function } \\
\hline TSH $(\mu \mathrm{U} / \mathrm{ml})$ & $141 \cdot 9 \pm 43 \cdot 0$ & $65 \cdot 6 \pm 38 \cdot 1^{\text {** }}$ \\
\hline$T_{3}(\mathrm{ng} / \mathrm{ml})$ & $0.45 \pm 0.24$ & $1 \cdot 06 \pm 0 \cdot 46^{* *}$ \\
\hline$T_{4}(\mu \mathrm{g} / \mathrm{dl})$ & $1 \cdot 23 \pm 1 \cdot 16$ & $3 \cdot 56 \pm 2 \cdot 47^{*}$ \\
\hline Free $T_{3}(\mathrm{pg} / \mathrm{ml})$ & $1 \cdot 16 \pm 0 \cdot 74$ & $2 \cdot 4 \pm 1 \cdot 08^{*}$ \\
\hline Free $T_{4}(\mathrm{ng} / \mathrm{dl})$ & $0 \cdot 18 \pm 0 \cdot 20$ & $0 \cdot 47 \pm 0 \cdot 25^{*}$ \\
\hline
\end{tabular}

\section{Animals and manipulation}

Five-week-old male Wistar rats were used in the experiments described in this study. We obtained 12 rats, weighing from 100 to $110 \mathrm{~g}$, from Shizuoka Laboratory Animal Center, Hamamatsu, Japan. The rats were divided into two groups of six on the basis of their initial body weights. Hypothyroidism in rats was induced by subcutaneous injection of MMI (Chugai Pharmaceutical Co., Ltd, Tokyo, Japan) at a daily dose of $1 \mathrm{mg}$ with concomitant oral administration of EPA-E (generously donated by Mochida Pharmaceutical Co., Ltd, Tokyo, Japan) at a daily dose of $300 \mathrm{mg} / \mathrm{kg}$ (or the same volume of saline as a control) for 4 weeks. After 4 weeks the rats were anesthetized with chloroform and blood samples and thyroid tissues were obtained. Part of the thyroid tissues were immediately frozen in liquid nitrogen and stored at $-80{ }^{\circ} \mathrm{C}$ until use. This work conformed to the guidelines on the handling of laboratory animals of our institution.

\section{Determination of serum tri-iodothyronine $\left(\mathrm{T}_{3}\right)$, thyroxine $\left(\mathrm{T}_{4}\right)$ and $\mathrm{TSH}$}

Serum levels of $T_{3}, T_{4}$ and TSH (patients) and $T_{3}$ and $T_{4}$ (animals treated with and without EPA-E) were measured by an immunochemiluminescence method (Amersham Pharmacia Biotech, Little Chalfont, UK); normal range of
$T_{3}, T_{4}$ and TSH concentrations are $0 \cdot 9-1.5 \mathrm{ng} / \mathrm{dl}, 5 \cdot 0-$ $9 \cdot 7 \mu \mathrm{g} / \mathrm{ml}$ and $0 \cdot 4-4 \cdot 0 \mu \mathrm{g} / \mathrm{ml}$ respectively. Serum levels of rat TSH were measured using a rat TSH (rTSH) enzyme immunoassay (EIA) system (Amersham Pharmacia Biotech); normal range of $\mathrm{rTSH}$ concentration is $5-30 \mathrm{ng} / \mathrm{ml}$.

\section{Analysis of plasma lipid and FFA composition}

At 9 weeks of age, after a 10-h fast, blood samples were taken from the tail veins of the rats without anesthesia. Plasma levels of total cholesterol, triglyceride and FFA were measured enzymatically with an autoanalyzer (Olympus Optical, Co., Ltd, Tokyo, Japan). FFAs were then separated and quantified by gas chromatography (model 663 Hitachi, Tokyo, Japan) using a capillary column (SP-2380).

\section{Analysis of FFA composition in thyroid tissues}

Thyroid tissues were obtained from the rats killed by exsanguination under anesthesia. Thyroid tissues were homogenized in a mixture of chloroform and methanol (2:1 vol./vol.), and total lipid extracts were prepared according to the method (Folch et al. 1957). The determination of FFA composition in the thyroid tissue extracts was performed as described for the determination of plasma FFA composition. 

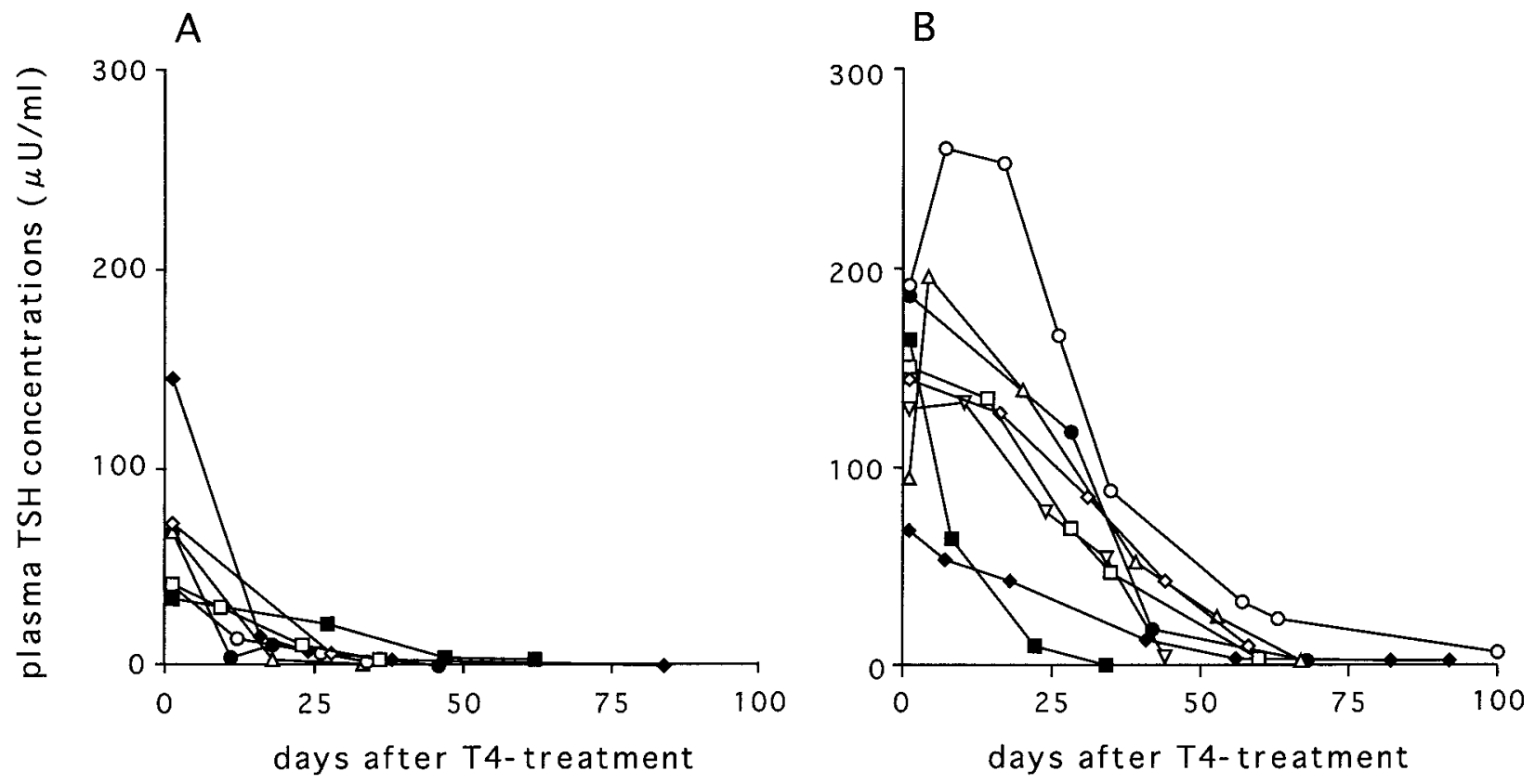

Figure 1 Change of serum TSH concentration in hypothyroid patients after $T_{4}$ treatment. (A) Seven hypothyroid patients with high plasma FFA levels. (B) Eight hypothyroid patients with low plasma FFA levels. The periods until normalization of TSH concentrations after the treatment of the patients with the high plasma FFA level were shorter than that of the patients with the low plasma FFA levels $(38 \cdot 1 \pm 12 \cdot 8$ vs $62 \cdot 6 \pm 12 \cdot 0, P<0 \cdot 01$, mean \pm S.D. $)$, and also the area under the curve was smaller $(1031 \cdot 0 \pm 487 \cdot 7 \mathrm{vs} 5599 \cdot 4 \pm 3177 \cdot 9$, $P<0 \cdot 01$, mean \pm S.D.).

\section{Histopathological examination}

The portions of thyroid tissues were immediately dissected and immersed in neutralized $10 \%$ formalin for 5 days. Specimens were then embedded in paraffin by routine procedures. Paraffin sections of the specimens were deparaffinized with xylene and stained with hematoxylin and eosin for light microscopy examination.

\section{Statistical analysis}

Data are expressed as the mean \pm S.D The significance of differences versus the control group was analyzed by Fisher's exact probability test (symptoms in hypothyroidism patients) or Mann-Whitney $U$ test (laboratory data in hypothyroidism patients and in animal study), and a statistically significant difference was defined at $P$ less than $0 \cdot 05$.

\section{Results}

\section{Clinical experiments}

Clinical and biochemical characteristics of hypothyroid patients Some hypothyroid patients had a higher plasma FFA concentration than normal range. The severity of hypothyroid symptoms and abnormal values of biochemical markers was elevated in those patients with low levels of plasma FFA (Table 1). Serum $T_{3}$ and $T_{4}$ concentrations were significantly decreased, and serum TSH concentrations were significantly increased, in patients with low plasma levels of FFA when compared with patients with high levels of plasma FFAs (Table 1).

Changes in TSH concentrations in patients with hypothyroidism after treatment Patients with high plasma levels of FFA exhibited more rapid normalization of TSH than patients with low plasma FFA (Fig. 1).

\section{Animal experiments}

Animal condition There were no significant differences in food intake and body weight of the MMI-induced hypothyroid animals during the experimental period (Table 2). Thyroid weight was, however, noticeably greater in animals treated without EPA-E than in animals treated with EPA-E (Table 2).

Lipid levels in thyroid tissues and plasma in hypothyroid rats Plasma FFA levels showed no statistically significant differences between animals treated with and without EPA-E during the experimental period (Table 2), nor was any significant difference observed between the groups in total cholesterol and triglyceride levels (Table 2). MMI-induced hypothyroid rats treated with EPA-E 


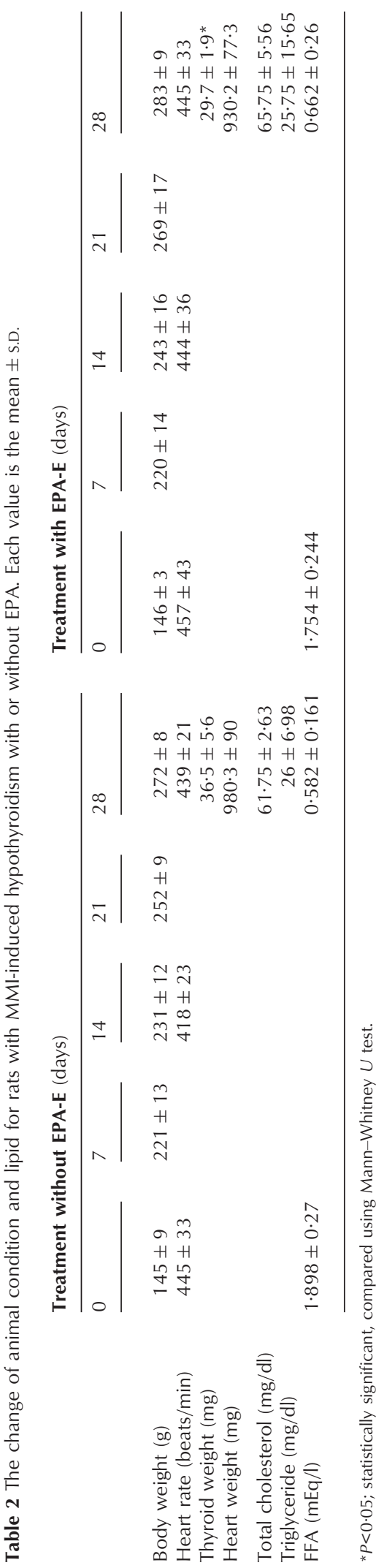

showed elevated level of EPA (C20:5) in plasma and thyroid tissues compared with hypothyroid rats treated without EPA-E (Table 3).

Changes in serum $T_{3}, T_{4}$ and rTSH levels in MMIinduced hypothyroid rats Hypothyroid rats treated with EPA-E exhibited significantly higher levels of serum $T_{3}$ and $T_{4}$ throughout the experimental period than rats treated with EPA-E (Fig. 2).

After these results were obtained, this experiment was reconfirmed by the same methods using seven rats from each group. Serum $T_{3}, T_{4}$ and rTSH levels of rats treated with EPA-E versus rats treated without EPA-E were $0.82 \pm 0.08$ vs $0.72 \pm 0.06 \mathrm{mg} / \mathrm{ml} \quad(P=0.0181), 4.63 \pm$ $0 \cdot 38$ vs $4 \cdot 10 \pm 0 \cdot 34 \mu \mathrm{g} / \mathrm{dl}(P=0 \cdot 0253)$, and $34 \cdot 58 \pm 8 \cdot 43$ vs $62 \cdot 26 \pm 11 \cdot 40 \mathrm{ng} / \mathrm{ml}(P=0 \cdot 017)$ respectively.

In addition, 5-week-old male Wistar rats were orally administrated with EPA-E at a daily dose of $300 \mathrm{mg} / \mathrm{kg}$ $(n=4)$ or the same volume of saline as a control $(n=4)$ for 4 weeks. The rTSH levels in rats treated with EPA-E were not significantly different from rats treated with saline: $9 \cdot 58 \pm 6 \cdot 36$ vs $13 \cdot 76 \pm 6 \cdot 88 \mathrm{ng} / \mathrm{ml}$.

Light microscopic findings Histopathological features in the thyroid tissues of hypothyroid rats are shown in Fig. 3. Although the size of the thyroid follicular lumens varied in MMI-induced hypothyroid rats treated without EPA-E (Fig. 3A), the size of the thyroid follicular lumens were uniform in MMI-induced hypothyroid rats treated with EPA-E (Fig. 3B).

\section{Discussion}

While several studies have shown that plasma FFA concentration in hypothyroidism is within normal range (Hamberger et al. 1963, Tulloch et al. 1973, Saunders et al. 1980), some hypothyroid patients have higher plasma FFA concentrations than the normal range in our investigation. In the clinical part of our study, we confirmed that symptoms of thyroid dysfunction in hypothyroid patients with high plasma FFA concentrations were less severe than those of patients with low plasma FFA concentration. Severely hypothyroid patients had lower FFA concentrations in this study, correlating with the fact that activities of lipoprotein lipase and hepatic triglyceride lipase, key enzymes of regulation in plasma FFA, are increased in hypothyroidism (Valdemarsson 1983). Hypothyroidism in patients with high plasma FFA concentrations was less severe, therefore we hypothesized that the increase of plasma FFA concentration might affect thyroid function in the hypothyroid state. To test our hypothesis, we examined the influence of the n-3 PUFA EPA-E on rats with MMI-induced hypothyroidism. In the animal experiments, the decrease in plasma $T_{3}$ and $T_{4}$ concentrations and increase in plasma TSH concentration 
Table 3 Changes in serum and thyroid FFA compositions for rats with MMl-induced hypothyroidism with or without EPA. Each value is the mean \pm S.D.

\begin{tabular}{|c|c|c|c|c|}
\hline & \multicolumn{2}{|l|}{ Plasma } & \multicolumn{2}{|l|}{ Thyroid } \\
\hline & EPA-E (-) & EPA-E $(+)$ & EPA-E $(-)$ & EPA-E (+) \\
\hline C14:0 & $0.32 \pm 0.05$ & $0.37 \pm 0.09$ & $1 \cdot 85 \pm 0 \cdot 30$ & $2 \cdot 00 \pm 0 \cdot 21$ \\
\hline C16:0 & $18 \cdot 92 \pm 0 \cdot 71$ & $19 \cdot 60 \pm 1 \cdot 32$ & $26 \cdot 77 \pm 1 \cdot 04$ & $28 \cdot 077 \pm 0.83$ \\
\hline C16:1 & $0 \cdot 82 \pm 0 \cdot 17$ & $1 \cdot 27 \pm 0 \cdot 17^{*}$ & $2.95 \pm 0.58$ & $3 \cdot 75 \pm 0 \cdot 41$ \\
\hline C18:0 & $14 \cdot 25 \pm 1 \cdot 66$ & $13 \cdot 32 \pm 1 \cdot 22$ & $9 \cdot 45 \pm 0.83$ & $7 \cdot 75 \pm 0.75$ \\
\hline C18:1 & $6.90 \pm 0.82$ & $6.97 \pm 0.69$ & $24 \cdot 30 \pm 2 \cdot 61$ & $24 \cdot 6 \pm 0 \cdot 79$ \\
\hline C18:2 & $20 \cdot 67 \pm 1 \cdot 05$ & $21 \cdot 02 \pm 1 \cdot 43$ & $24 \cdot 22 \pm 2 \cdot 13$ & $24 \cdot 47 \pm 2 \cdot 30$ \\
\hline C18:3 & $0 \cdot 35 \pm 0 \cdot 05$ & $0 \cdot 35 \pm 0.05$ & $0 \cdot 75 \pm 0 \cdot 12$ & $0.95 \pm 0 \cdot 17^{*}$ \\
\hline C20:0 & $0 \cdot 12 \pm 0 \cdot 05$ & $0 \cdot 10 \pm 0 \cdot 00$ & $0 \cdot 17 \pm 0 \cdot 05$ & $0 \cdot 20 \pm 0 \cdot 00$ \\
\hline C20:1 & $0.12 \pm 0.05$ & $0 \cdot 10 \pm 0 \cdot 00$ & $0.52 \pm 0.05$ & $0.50 \pm 0.00$ \\
\hline C20:2 & $0.22 \pm 0.00$ & $0.22 \pm 0.00$ & $0.30 \pm 0.00$ & $0.32 \pm 0.05$ \\
\hline C20:3 & $0.77 \pm 0.09$ & $1 \cdot 1 \pm 0 \cdot 18$ & $0 \cdot 42 \pm 0 \cdot 12$ & $0.35 \pm 0.05$ \\
\hline C20:4 & $29 \cdot 02 \pm 1 \cdot 61$ & $25 \cdot 17 \pm 3 \cdot 52$ & $4 \cdot 25 \pm 1 \cdot 33$ & $2 \cdot 87 \pm 0 \cdot 33$ \\
\hline C20:5 & $1 \cdot 15 \pm 0 \cdot 17$ & $3 \cdot 22 \pm 0 \cdot 66^{* *}$ & $0 \cdot 20 \pm 0.08$ & $0.62 \pm 0.09^{* *}$ \\
\hline C22:0 & $0.17 \pm 0.05$ & $0 \cdot 25 \pm 0.05$ & $0.17 \pm 0.05$ & $0.22 \pm 0.05$ \\
\hline C22:1 & ND & ND & ND & ND \\
\hline C22:5 & $0.85 \pm 0 \cdot 20$ & $1.77 \pm 0.69$ & $0.92 \pm 0.15$ & $1 \cdot 55 \pm 0.28$ \\
\hline C22:6 & $5 \cdot 05 \pm 0 \cdot 26$ & $4 \cdot 80 \pm 0 \cdot 76$ & $2 \cdot 50 \pm 1.08$ & $1 \cdot 60 \pm 0 \cdot 29$ \\
\hline C24:0 & $0 \cdot 10 \pm 0 \cdot 00$ & $0 \cdot 17 \pm 0 \cdot 15$ & $0.01 \pm 0 \cdot 00$ & $0 \cdot 17 \pm 0 \cdot 00$ \\
\hline C24:1 & $0 \cdot 10 \pm 0 \cdot 00$ & $0 \cdot 10 \pm 0 \cdot 00$ & $0.05 \pm 0.00$ & $0 \cdot 10 \pm 0 \cdot 00$ \\
\hline
\end{tabular}

${ }^{*} P<0 \cdot 05,{ }^{*} P<0 \cdot 01$; statistically significant, compared using Mann-Whitney $U$ test.

in the MMI-induced hypothyroid state was inhibited by administration of EPA-E. In addition, the sizes of the thyroid follicles without administration of EPA-E were varied and contained large of quantities of colloid. These findings indicate that thyroid hormone secretion in the rat in the absence of EPA-E administration is elevated.

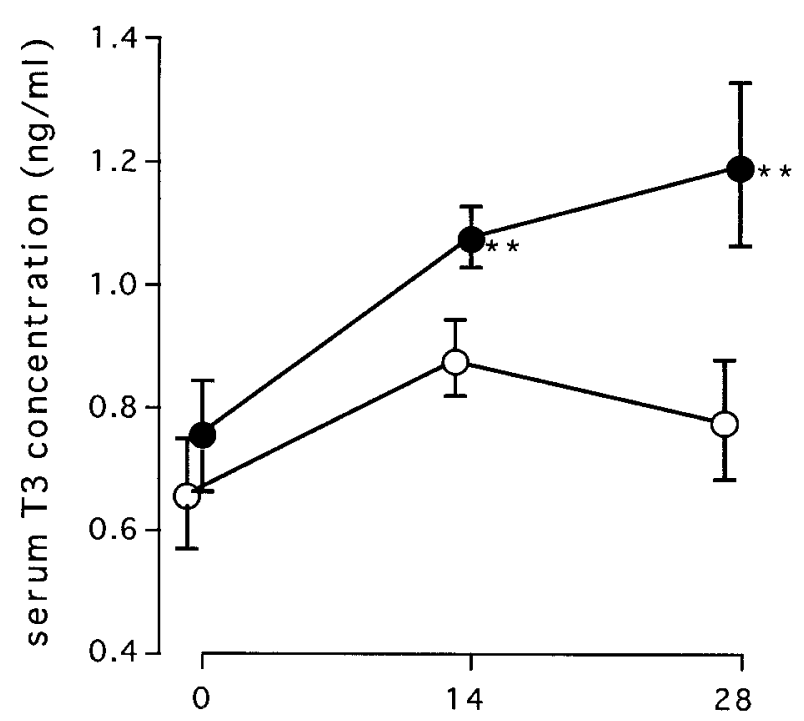

days after the treatment
The regulation of cell functions by PUFA, including EPA, might occur on two general levels: modulation of signal transduction via manipulation of membrane fatty acid composition; and rapid, direct modulation of gene transcription. Several studies have provided evidence indicating that plasma membrane lipids in thyroid glands

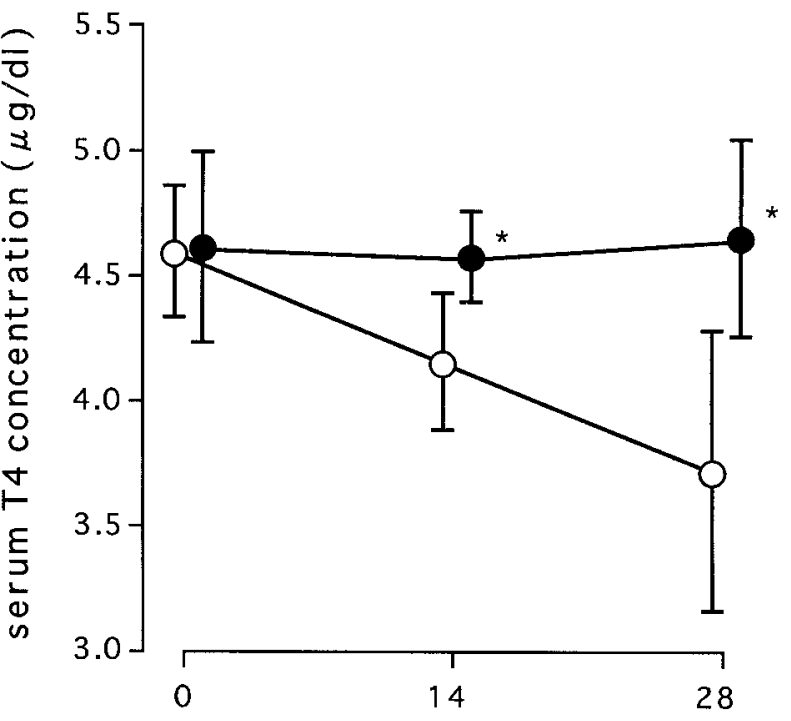

days after the treatment

Figure 2 Changes in serum $T_{3}(\mathrm{ng} / \mathrm{dl})$ and $T_{4}(\mu \mathrm{g} / \mathrm{ml})$ concentration for MMl-induced hypothyroid rats treated with $(\mathbf{O})$ or without $(\bigcirc)$ EPA-E. Each value represents the mean \pm S.D. ${ }^{* *} P<0 \cdot 01,{ }^{*} P<0 \cdot 05$. 
(a)

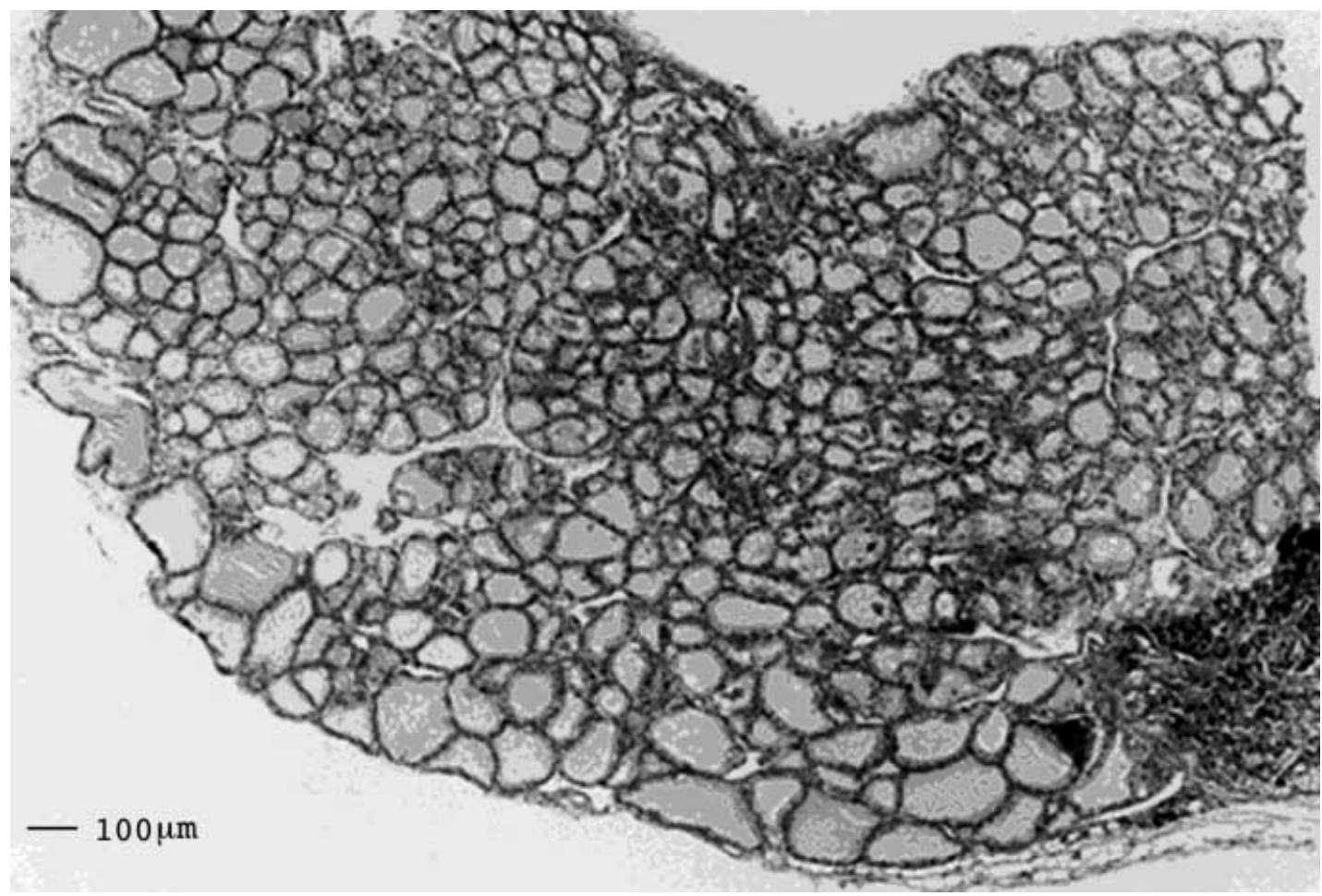

(b)

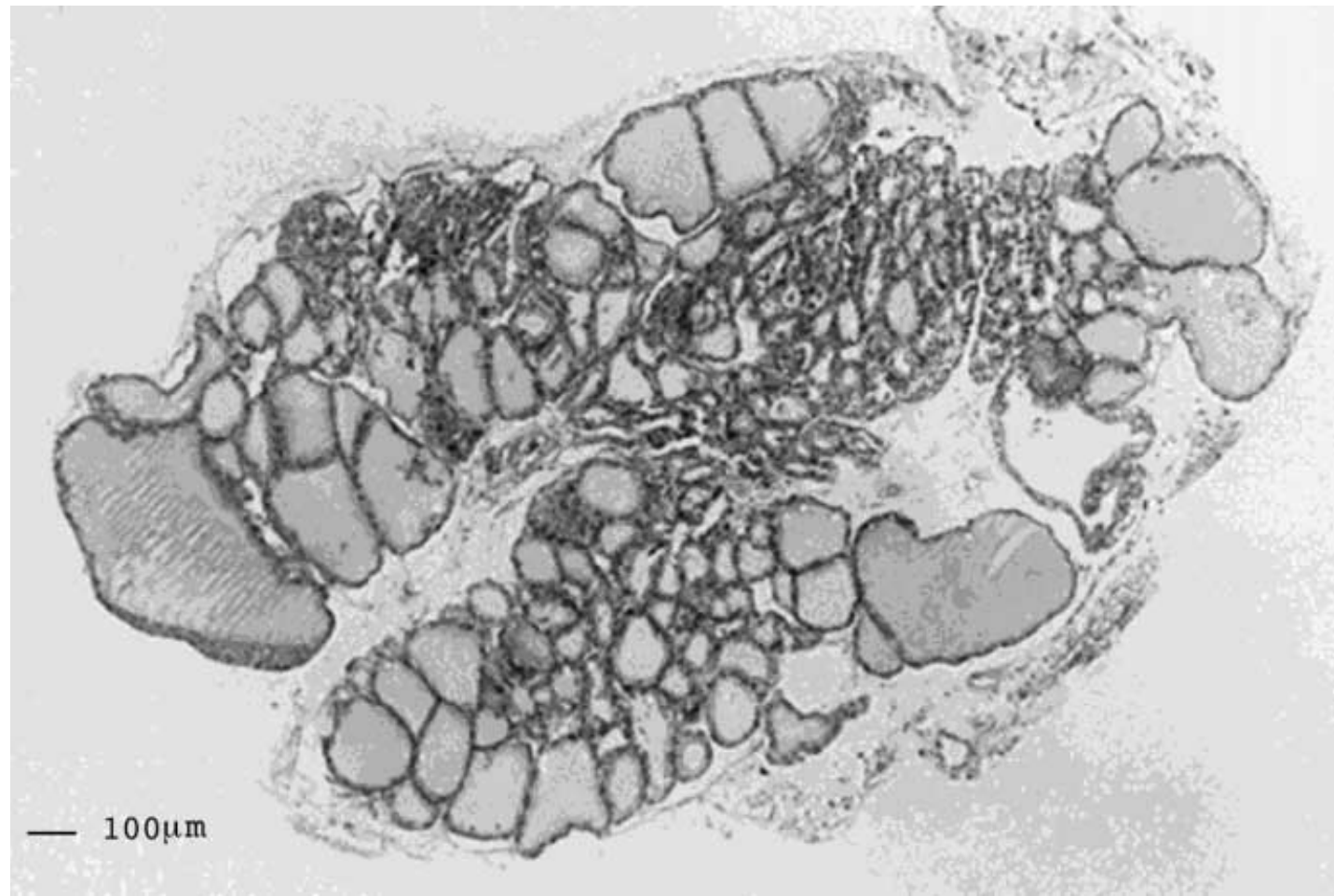

Figure 3 Histopathological analysis of the thyroid glands of MMl-induced hypothyroid rats treated with (A) or without (B) EPA-E. 
modulate the TSH receptor and its ability to bind TSH (Bashford et al. 1975, Mehedi et al. 1977, Omodeo-Sale et al. 1978, Aloj et al. 1979). Furthermore, an important role for phospholipids has been indicated in the TSHresponsive adenylate cyclase system (Macchia et al. 1970, Yamashita et al. 1970, Yamashita \& Field 1973, Moore \& Wolff 1974, Amir et al. 1976).

EPA and arachidonic acid (AA), constituents of the plasma membrane, are metabolized via the cyclooxygenase, lipooxygenase or epoxygenase pathways to generate eicosanoids. Eicosanoids produced from EPA and AA have different effects in their actions ( $\mathrm{Yu}$ et al. 1995). These differences may affect receptor and signal transduction, resulting in the changes of thyroid hormone biosynthesis or release.

PUFAs are ligands for PPAR $\alpha$ (Forman et al. 1997, Kliewer et al. 1997), a member of the nuclear receptor superfamily. PPAR $\alpha$ is related to cell proliferation and differentiation in hepatocytes (Peters et al. 2000), keratinocytes (Hanley et al. 1998) and oval cells (Kaplanski et al. 2000). Although a relationship between PPAR $\alpha$ and thyroid follicular cells is not apparent in cellular growth and function, it is possible that PPAR $\alpha$ affects thyroid follicular cell proliferation and differentiation.

It is clear that administration of EPA-E inhibits the decrease in thyroid hormone levels. It will be interesting to determine whether other PUFAs, such as AA and docosapentaenoic acid, have the same effect. Our findings suggest that FFA may affect thyroid functions, and that EPA-E may prevent MMI-induced hypothyroidism.

\section{References}

Aloj SM, Lee G, Evelyn F, Grollman F, Beguinot F, Consiglio E \& Kohn LD 1979 Role of phospholipids in the structure and function of the thyrotropin receptor. Journal of Biological Chemistry 254 9040-9049.

Amir SM, Goldfine ID \& Ingbar SH 1976 Properties of the interaction between bovine thyrotropin and bovine thyroid plasma membranes. Journal of Biological Chemistry 251 4693-4699.

Bashford CL, Harrison SJ \& Radda GK 1975 The relation between lipid mobility and the specific hormone binding of thyroid membranes. Biochemical Journal 146 473-479.

Ekokoski E, Forss L \& Tornquist K 1994 Inhibitory action of fatty acids on calcium fluxes in thyroid FRTL-5 cells. Molecular and Cellular Endocrinology 103 125-132.

Folch J, Less M \& Stanley GHS 1957 A simple method for the isolation and purification of total lipids from animal tissues. Journal of Biological Chemistry 226 497-507.

Forman BM, Chen J \& Evans RM 1997 Hypolipidemic drugs, polyunsaturated fatty acids, and eicosanoids are ligands for peroxisome proliferator-activated receptor $\alpha$ and $\gamma$. PNAS 94 4312-4317.

Gould RJ, Ginsberg BH \& Spector AA 1982 Lipid effects on the binding properties of a reconstituted insulin receptor. Journal of Biological Chemistry 257 477-484.
Hamberger J, Smith RW \& Miller JM 1963 Effects of epinephrine on free fatty acid metabolism in hyperthyroid and hypothyroid subjects. Metabolism 12 821-828.

Hanley K, Jiang Y, He SS, Friedman M, Elias PM, Bikle DD, Williams ML \& Feingold KR 1998 Keratinocyte differentiation is stimulated by activators of the nuclear hormone receptor $\operatorname{PPAR} \alpha$. Journal of Investigative Dermatology 110 368-375.

Hoch FL 1988 Lipid and thyroid hormones. Progress in Lipid Research 27 199-270.

Kaplanski C, Pauley CJ, Griffiths TG, Kawabata TT \& Ledwith BJ 2000 Differentiation of rat oval cells after activation of peroxisome proliferator-activated receptor $\alpha 43$. Cancer Research 60 580-587.

Kliewer SA, Sundseth SS, Jones SA, Brown PJ, Wisely GB, Koble CS, Devchand P, Wahli W, Willson TM, Lenhard JM \& Lehmann JM 1997 Fatty acids and eicosanoids regulate gene expression through direct interactions with peroxisome proliferator-activated receptors $\alpha$ and $\gamma$. PNAS 94 4318-4323.

Kromann N \& Green A 1980 Epidemiological studies in the upernavik district, Greenland. Acta Medica Scandinavica 208 401-406.

Macchia V, Tamburrini O \& Pastan I 1970 Role of lecithin in the mechanism of TSH action. Endocrinology 86 787-792.

Mehedi SQ, Nussey SS, Shindelman JE \& Kriss JP 1977 The influence of lipid substitution on thyrotropin-receptor interactions in artificial vesicles. Endocrinology 101 1406-1412.

Moore WV \& Wolff J 1974 Thyroid-stimulating hormone binding to beef thyroid membranes. Journal of Biological Chemistry 249 6255-6263.

Neelands PJ \& Clandinin MT 1983 Diet fat influences liver plasmamembrane lipid composition and glucagon-stimulated adenylate cyclase activity. Biochemical Journal 212 573-583.

Omodeo-Sale F, Brandy RO \& Fishman PH 1978 Effect of thyroid phospholipids on the interaction of thyrotropin with thyroid membranes. PNAS 75 5301-5305.

Peters JM, Rusyn I, Rose ML, Gonzalez FJ \& Thurman RG 2000 Peroxisome proliferator-activated receptor $\alpha$ is restricted to hepatic parenchymal cells, not Kupffer cells: implications for the mechanism of action of peroxisome proliferators in hepatocarcinogenesis. Carcinogenesis 21 823-826.

Saunders J, Hall SHE \& Sonksen PH 1980 Glucose and free fatty acid turnover in thyroxicosis and hypothyroidism, before and after treatment. Clinical Endocrinology 13 33-44.

Tulloch BR, Lewis B \& Fraser TR 1973 Triglyceride metabolism in thyroid disease. Lancet $\mathbf{7 8 0 2}$ 391-394.

Valdemarsson S 1983 Plasma lipoprotein alterations in thyroid dysfunction. Role of lipoprotein lipase, hepatic lipase and LCAT. Acta Endcrinologica (Suppl) 255 1-52.

Yamashita K \& Field JB 1973 The role of phospholipids in TSH stimulation of adenylate cyclase in thyroid plasma membranes. Biochimica et Biophysica Acta 304 686-692.

Yamashita K, Bloom G, Zor BRU \& Field JB 1970 Effect of chloropromazine, propranolol and phospholipase $\mathrm{C}$ on thyrotropin and prostaglandin stimulation of adenyl cyclase-cyclic AMP system in dog thyroid slices. Metabolism 19 1109-1118.

Yu K, Bayona W, Kallen CB, Harding HP, Ravera CP, McMahon G, Brown M \& Lazar MA 1995 Differential activation of peroxisome proliferator-activated receptors by eicosanoids. Journal of Biological Chemistry 270 23975-23983.

Received in final form 16 July 2001 Accepted 24 July 2001 